\title{
Theoretical saturation in qualitative research: an experience report in interview with schoolchildren
}

\author{
Saturação teórica em pesquisa qualitativa: relato de experiência na entrevista com escolares
}

Saturación teórica en investigación cualitativa: relato de experiencia en la entrevista con escolares

\section{Luciana de Cassia Nunes Nascimento', Tania Vignuda de Souza', Isabel Cristina dos Santos Oliveira', Juliana Rezende Montenegro Medeiros de Moraes", Rosane Cordeiro Burla de Aguiar"II, Liliane Faria da Silva'"I \\ ' Universidade Federal do Rio de Janeiro, Postgraduate Program in Nursing. Rio de Janeiro, Brazil. ' Universidade Federal do Rio de Janeiro, Anna Nery School of Nursing, Department of Maternal-Child Nursing. Rio de Janeiro, Brazil. \\ II' Universidade Federal Fluminense, Aurora de Afonso Costa Nursing School, Maternal-Child Department and Psychiatry. Niterói, Rio de Janeiro, Brazil.}

How to cite this article:

Nascimento LCN, Souza TV, Oliveira ICS, Moraes JRMM, Aguiar RCB, Silva LF. Theoretical saturation in qualitative research: an experience report in interview with schoolchildren.

Rev Bras Enferm [Internet]. 2018;71(1):228-33. DOI: http://dx.doi.org/10.1590/0034-7167-2016-0616

Submission: 12-20-2016 Approval: 04-10-2017

\begin{abstract}
Objective: report the experience of applying the theoretical data saturation technique in qualitative research with schoolchildren. Method: critical reading of primary sources and compilation of raw data, followed by thematic grouping through colorimetric codification and allocation of themes/types of statements in charts to find theoretical saturation for each grouping. Results: colorimetric codification occurred according to previously established themes: bodily hydration; physical activities and play; handling of sickle-cell disease; feeding and clothing. On the eleventh interview, it was possible to reach the theoretical saturation of themes, with four additional interviews being performed. Conclusion: this experience report enabled the description of the five sequential steps for identification of theoretical data saturation in qualitative research conducted with schoolchildren.
\end{abstract}

Descriptors: Data Curation; Qualitative Research; Sampling; Data Collection; Child.

\section{RESUMO}

Objetivo: relatar a experiência na aplicação técnica de saturação teórica dos dados em pesquisa qualitativa com escolares. Método: leitura crítica das fontes primárias e compilação dos dados brutos, seguidas do agrupamento temático por meio da codificação colorimétrica e alocação dos temas/tipos de enunciados em um quadro para constatação da saturação teórica de cada agrupamento. Resultados: a codificação colorimétrica ocorreu de acordo com os temas estabelecidos previamente: hidratação corporal; brincadeiras e atividades físicas; manejo da doença falciforme; alimentação e roupas utilizadas. Na décima primeira entrevista foi possível alcançar a saturação teórica dos temas, sendo, após, realizadas mais quatro entrevistas. Conclusão: este relato de experiência permitiu descrever os cinco passos percorridos sequencialmente para identificação da saturação teórica dos dados em uma pesquisa qualitativa desenvolvida com escolares. Descritores: Validação de Dados; Pesquisa Qualitativa; Amostragem; Coleta de Dados; Criança.

\section{RESUMEN}

Objetivo: Relatar la experiencia en la aplicación técnica de saturación teórica de datos en investigación cualitativa con escolares. Método: Lectura crítica de fuentes primarias y compilación de datos brutos, continuadas por agrupado temático mediante codificación colorimétrica y ubicación de los temas/tipos de enunciado en un cuadro para constatación de saturación teórica de cada grupo. Resultados: La codificación colorimétrica se realizó según los temas previamente establecidos: hidratación corporal; bromas y actividades físicas; manejo de la enfermedad falciforme, alimentación y ropas utilizadas. En la decimoprimera entrevista fue posible alcanzar la saturación teórica de los temas, realizándose luego cuatro entrevistas más. Conclusión: Este 
relato de experiencia permitió describir los cinco pasos seguidos secuencialmente para la identificación de saturación teórica de datos en una investigación cualitativa desarrollada con escolares.

Descriptores: Validación de Datos; Investigación Cualitativa; Muestreo; Colecta de Datos; Niño.

\section{INTRODUCTION}

The expression theoretical saturation, employed in qualitative research, considers that, when data are collected, there is a transference of psychocultural significations from their original environment, from individuals or groups, to another environment, that of the researcher ${ }^{(1)}$. Data collection is considered saturated when no new elements are found and the addition of new information ceases to be necessary, since it does not alter the comprehension of the researched phenomenon. It is a criterion that enables the establishment of the validity of a data set ${ }^{(2)}$.

In this context, researchers must explain the factors they found to be involved in the creation of the theoretical configuration being presented. This is important, because although the interpretative models in qualitative research are not fully linked to the positivist tradition, this type of research is not exempt from being assessed for the methodological accuracy employed at its every stage and must transparently express how the theoretical saturation was achieved, in order to show this accuracy in the scientific investigation ${ }^{(1,3)}$.

Theoretical data saturation is also found in scientific literature as an external validation, since it is related to research results.

Validation in qualitative research is a theme that has been explored for over five decades, with more emphasis in recent years. Although its presuppositions have been initially designed for quantitative research, qualitative research has been increasingly appropriating them. The goal of adopting validation methods according to the objectives of each research consists of an integrative perspective, whose aim is to reach a holistic validity proposal, protecting studies from taking wrong routes and results ${ }^{(4)}$.

It is possible to observe that such concepts regarding validity can be grouped into three large blocks. It is possible to mention those more related to the phases of: research formulation (previous validity), research development (internal validity) and research results (external validity). Validity in qualitative research seems to be larger and more specific, although less quantitatively measurable ${ }^{(5)}$.

When developing qualitative research, authors frequently face the challenge of transparently describing the steps taken in the identification of the adequate moment to stop data collection and attain theoretical saturation.

Transparence is understood as the quality that allows research readers to clearly understand the processes conducted by researchers during data collection and analysis for theoretical construction. It is a reliability criterion adopted in qualitative research ${ }^{(6-7)}$.

The saturation criterion is a process for the objective validation of research that adopts methods, addresses themes and collects information in sectors and areas where it is unfeasible or unnecessary to probabilistically treat samples. It is one of the ways to handle sampling paradox. Sampling paradox manifests as follows: the sample is useless if it is not truly representative of the population ${ }^{(2)}$.
The most common way to employ the saturation criterion is applying semi-structured interviews sequentially, with open-ended questions. The researcher identifies the types of responses and records repetitions. When no new information or no new theme is recorded, the point of saturation is found. The investigation scheme is simple. However, in practice, it is difficult to define the criterion to cease collection or interrupt interviews, in other words, for preparing the sample ${ }^{(2)}$.

In this context, the objective of this study was to report an experience of technical application of theoretical data saturation in qualitative research with schoolchildren.

\section{METHOD}

This study is an experience report whose motivation came after attaining theoretical data saturation in a doctoral thesis, which were collected through semi-structured interviews conducted with school children carriers of sickle cell disease. The study was approved by the human research ethics committees of the proponent and co-participating institutions.

Two interviews were conducted previously in order to validate the script (internal validation), seeking to meet the goals of the thesis and adjust the questions to avoid dubious interpretations, doubts and/or response variety, which could compromise the method's accuracy, data obtainment and, afterwards, attainment of theoretical saturation.

When the interview is conducted in an isolated way, maintaining participant privacy, representativity is better guaranteed by the generic investigation conditions. Still regarding the creation of questions, formulations with dubious meanings and questions that allow broad responses must be avoided. Such caution maximizes accuracy and reduces the number of interviews necessary for saturation ${ }^{(2)}$. Data collection began after instrument validation, and lasted from May, 2015, to March, 2016.

In order to determine when theoretical saturation would be reached in primary sources, five procedural steps were followed ${ }^{(3)}$ :

Step 1 - Recording of raw data (primary sources): In total, 15 schoolchildren carriers of sickle cell disease were interviewed. Since the beginning of collection, interviews were recorded with authorization of the legal guardians and consent from children and were immediately transcribed in full.

Step 2 - Immersion in data: thorough reading of data obtained through interviews as they were conducted.

Step 3 - Compilation of individual analyses of each interview and thematic grouping: when performing thorough reading, the themes play and physical activities, feeding, handling sickle cell disease, bodily hydration, elimination and clothes were organized through colorimetric codification.

Step 4 - Theme allocation and types of statements in one chart: data presentation in a chart made it possible to find regularity in 
findings in speeches, according to the themes, and the verification of statement consistency (Chart 1), in which " $R$ " is the researcher and "S", schoolchild. Thus, by applying the colorimetric method, responses related to play and physical activities were highlighted in yellow, feeding in light-blue, handling of sickle cell disease in gray, bodily hydration in pink, elimination in red and clothing in green.

Step 5 - Attainment of theoretical data saturation through absence of new elements for each grouping.

\section{RESULTS}

Below is presented an excerpt from interview with a 6-year old schoolchild carrier of sickle cell disease, after transcription and application of the colorimetric method.
After colorimetric codification and grouping of related themes (Chart 1), the authors sought to demonstrate how the occurrence of new statements was distributed. The theme bodily hydration was elected to move forward with the description of the procedural steps taken for attaining theoretical saturation.

Concerning bodily hydration, the item related to elimination presented new elements up to the second interview. As for the types of liquids ingested, there was no identification of new elements starting in the fourth interview, and regarding the importance of liquids, new elements appeared up to the fourteenth interview. In chart 2, there is an example of grouping of types of liquids ingested that emerged from each children's (letter C) interview (letter I).

Chart 1 - Interview with a schoolchild after application of the colorimetric method and grouping of themes (Steps 3 and 4)

\begin{tabular}{|c|c|c|}
\hline Researcher & Schoolchild & Themes \\
\hline $\begin{array}{l}\text { R: Are there any games that you think can influence } \\
\text { your health? Why? }\end{array}$ & $\begin{array}{l}\text { S: Hide and seek behind my grandmother's house, in the } \\
\text { shade. That is because I get ill under the sun, with pain } \\
\text { in my back, in my stomach, in my arm, in my leg and } \\
\text { headaches because of the sickle cell anemia. That is when a } \\
\text { person feels pain. } \\
\text { S: Pool. When I stay in too long, I feel arm pain, stomach } \\
\text { pain, back pain, leg pain... because there is a pool in my } \\
\text { house, then, when I got in and stayed in too long with my } \\
\text { cousin, I felt pain. }\end{array}$ & $\begin{array}{l}\text { Play and } \\
\text { physical } \\
\text { activities }\end{array}$ \\
\hline R: I understand. And what do you usually eat? & S: Macaroni and filled cookies. & \\
\hline $\begin{array}{l}\text { R: Among the foods you usually eat, which ones are } \\
\text { good for your health? }\end{array}$ & S: Rice, beans, meat and salad and sausage. & Feeding \\
\hline $\begin{array}{l}\text { R: And among the foods you usually eat, which ones } \\
\text { are not good for your health? }\end{array}$ & S: And candy. My mom said I cannot eat candy. & \\
\hline $\begin{array}{l}\text { R: I understand. I want to know if you take any } \\
\text { medication, drugs at home? }\end{array}$ & S: Hydroxyurea, not to feel pain. & \\
\hline $\begin{array}{l}\text { R: With whom did you learn this information on the } \\
\text { drugs? }\end{array}$ & $\begin{array}{l}\text { S: With the doctor. She said I have to take them. Back } \\
\text { home, my mother put the powder that came inside the } \\
\text { capsule in water for me to drink, but it did not work. I did } \\
\text { not improve, so, I had to take it whole. }\end{array}$ & $\begin{array}{l}\text { Handling of } \\
\text { sickle cell } \\
\text { disease }\end{array}$ \\
\hline R: Who takes care of you when you are sick? & $\begin{array}{l}\text { S: My mom. She gives me medicine. And when my pain } \\
\text { increases, she goes to the hospital with me. }\end{array}$ & \\
\hline R: And what do you do to take care of your health? & S: I take some medicine and go to the doctor. & \\
\hline $\begin{array}{l}\text { R: What do you usually drink in breakfast, lunch, } \\
\text { snack time, dinner and in-between? }\end{array}$ & $\begin{array}{l}\text { S: Water, pop, chocolate milk, juice, a little. In the school, } \\
\text { water, a little. }\end{array}$ & \\
\hline R: How is it to you to use the school bathroom? & $\begin{array}{l}\text { S: You always can, but when we go inside the classroom, } \\
\text { the teacher does not allow us. We have to drink water and } \\
\text { go to the bathroom so we do not feel the need. }\end{array}$ & \\
\hline R: Why is it important to drink liquids? & S: Because we die if we do not drink water. & $\begin{array}{l}\text { Bodily } \\
\text { hydration }\end{array}$ \\
\hline $\begin{array}{l}\text { R: And among these liquids you usually drink, which } \\
\text { ones are good for your health? }\end{array}$ & S: Water, pop... & \\
\hline $\begin{array}{l}\text { R: And among the liquids you usually drink, which } \\
\text { ones are not good for the health? }\end{array}$ & S: None here. & \\
\hline
\end{tabular}




\begin{tabular}{|l|l|l|}
\hline \multicolumn{1}{|c|}{ Researcher } & \multicolumn{1}{c|}{ Schoolchild } \\
\hline $\begin{array}{l}\text { R: Let us discuss clothing, then? How do you usually } \\
\text { dress in cold days? }\end{array}$ & S: Coat, pants, sweater and a cap. \\
$\begin{array}{l}\text { R: Why do you dress like that when it is cold? } \\
\text { R: And when the day is too hot? }\end{array}$ & $\begin{array}{l}\text { S: Because. } \\
\text { S: Light clothes. } \\
\text { R: Does someone tell you how you should dress? }\end{array}$ & $\begin{array}{l}\text { S: Yes, my mother. When it is cold, she tells me to put on pants } \\
\text { and sweaters. When it is hot, to put on a blouse and shorts. }\end{array}$ \\
\hline
\end{tabular}

Only the types of liquids ingested were considered, such as juice and tea, independently of their flavor. At the time of data transcription, some citations from schoolchildren related to commercial brands were substituted for generic terms to meet the ethical criteria of the research.

Chart 2 - Attainment of theoretical saturation in the theme of bodily hydration: Types of liquids ingested (Step 5)

\begin{tabular}{|c|c|}
\hline Schoolchild & $\begin{array}{l}\text { Report from schoolchildren } \\
\text { on types of liquids ingested }\end{array}$ \\
\hline E1 & $\begin{array}{l}\text { milk with coffee...tea. I like chamomile, chocolate } \\
\text { milk... I do not like milk so much...I drink soda... } \\
\text { natural juices. At school, water, too. (C1, } 12 \text { years) }\end{array}$ \\
\hline E2 & $\begin{array}{l}\text { Juice and milk... Water and juice... made of cocoa... } \\
\text { Yeah... made with those icy bags (pulp)... sometimes } \\
\text { it is milk... water...and pop, too. At school I drink juice, } \\
\text { one glass (C2, } 7 \text { years) }\end{array}$ \\
\hline E3 & $\begin{array}{l}\text { Milk, water and juice. At school, I drink juice and } \\
\text { chocolate milk (C3, } 10 \text { years) }\end{array}$ \\
\hline E4 & $\begin{array}{l}\text { Sometimes I drink coffee... Sometimes, I drink juice... } \\
\text { Water, milk, tea. At school, juice... Sometimes, } \\
\text { because I do not like some juices... I drink milk and } \\
\text { banana smoothies. A full glass, but I do not drink it } \\
\text { all. (C4, } 12 \text { years) }\end{array}$ \\
\hline E5 & $\begin{array}{l}\text { At school, I drink juice, chocolate milk, water, coffee. } \\
\text { At home, I drink very little. At my aunt's, I drink one } \\
\text { glass of chocolate milk (C5, } 9 \text { years) }\end{array}$ \\
\hline E6 & $\begin{array}{l}\text { Water, a lot during the day because there is no soda at } \\
\text { my house. At school I drink water, two glasses (C6, } 6 \\
\text { years) }\end{array}$ \\
\hline E7 & $\begin{array}{l}\text { Water, pop, chocolate milk, juice, a little. At } \\
\text { school, water, a little (C7, } 6 \text { years) }\end{array}$ \\
\hline E8 & $\begin{array}{l}\text { At school, I drink a glass of chocolate milk, juice. } \\
\text { They do not give you anything to drink with lunch } \\
\text { at school. Then, when I finish eating, I drink water } \\
\text { from the fountain. At home, I drink coffee, a box of } \\
\text { juice or soda (C8, } 12 \text { years). }\end{array}$ \\
\hline E9 & $\begin{array}{l}\text { At home I drink half a glass of coffee, half a glass } \\
\text { of soda. And at school, lots of water, but always in } \\
\text { half glasses (C9, } 12 \text { years) }\end{array}$ \\
\hline E10 & Coffee. Juice, milk and sugar, water (C10, 12 years) \\
\hline
\end{tabular}

To be continued
Chart 2 (concluded)

\begin{tabular}{|c|c|}
\hline Schoolchild & $\begin{array}{l}\text { Report from schoolchildren } \\
\text { on types of liquids ingested }\end{array}$ \\
\hline E11 & $\begin{array}{l}\text { Coffee, I drink water, chocolate milk (C11, } 10 \\
\text { years) }\end{array}$ \\
\hline E12 & $\begin{array}{l}\text { Milk with coffee and juice at school. (At home) tea } \\
\text { when it is late at night... First I drink water, then I } \\
\text { drink coffee and milk. Sometimes, chocolate milk. } \\
\text { Juice... Juice and water (C12, } 11 \text { years) }\end{array}$ \\
\hline E13 & $\begin{array}{l}\text { Milk with coffee at school. Coffee, water, milk... } \\
\text { Tea, chocolate milk, sometimes, at home (C13, } 12 \\
\text { years) }\end{array}$ \\
\hline E14 & $\begin{array}{l}\text { Milk or chocolate milk, juice when I wake up and } \\
\text { after that, water }(\mathrm{C} 14,11 \text { years) }\end{array}$ \\
\hline E15 & $\begin{array}{l}\text { Chocolate milk, coffee, at school. Juice and water } \\
\text { at home (C15, } 6 \text { years) }\end{array}$ \\
\hline
\end{tabular}

The school children mentioned ingesting a variety of liquids, such as milk, coffee, tea, chocolate milk, soft drinks, juice, water and smoothies. The last new element, found in the interview with C4, 12 years, was milk and honey smoothie. Chart 2 showed that, after the fourth interview, no new elements rose regarding types of liquids ingested by school children with sickle cell disease and, at this stage, it was determined that theoretical densification was possible, according to analysis of empirical data by the researchers.

Regarding play and physical activities, whether active or passive, theoretical saturation for this element was attained in the second interview. When questioned about the types of play or physical activities involved, new elements were identified in statements up to the ninth interview.

Regarding the coping with sickle cell disease, referring to the employment of regular use maintenance medication such as hydroxyurea and folic acid, data saturation was attained in the second interview. Regarding the search for health services, there were no new elements since the second interview. As for the use of medication for health recovery, such as painkillers, antipyretics and bronchodilators, there were new elements up to the fifth interview. Regarding the identification of factors that trigger crises, no new elements were found by the eighth report.

Considering that the foods ingested are very diversified, they were grouped by fruits, meats, pastas, vegetable a (leaves), vegetal B (legumes), vegetal C (potatoes, cassava, yam, sweet 
potatoes), cereals and leguminous. Therefore, the absence of new elements occurred by the second interview. In the classification of foods that harm one's health according to school children, new data rose up to the fifth interview and, in the classification of healthy foods, up to the eighth. Concerning the consumption of foods considered unhealthy for children, such as candy, cookies, popcorn and fried foods, new data were observed up to the ninth interview.

Regarding the use of clothing adequate for the weather or environmental temperature, no new elements were found starting from the second interview.

\section{DISCUSSION}

Initially, in order to find theoretical data saturation, it was necessary to make the whole material available ${ }^{(3)}$, which, for this study, was obtained through the interview technique.

As the interviews are conducted, researchers must explore them individually ${ }^{(3)}$, since the assessment of theoretical saturation based on a sample is performed according to a continuous process of data analysis, which begins in the collection phase ${ }^{(8)}$.

In sequence, the researcher must compile and group the themes found. They must also mark the transcriptions in paragraphs, simplifying the handling of these excerpts, which helps immediately identifying participants and the point in the interviews where they were asserted ${ }^{(3)}$. The use of colorimetric codification highlighted the themes related to the children with sickle cell disease, an aspect that made it easier to group and find each excerpt in the interview.

Allocating data this way also made it possible to visualize the analytic elements and to learn how they are distributed during the conducted interviews ${ }^{(3)}$. Thus, it was possible to find the themes that emerged from the empirical material.

After this stage, theoretical saturation of the aforementioned themes presented itself by the absence of new elements in the treated material. In qualitative studies using interviews as data collection strategies, saturation is attained when data after analysis are consistent in quality and quantitative density ${ }^{(9)}$.

Another method for researchers to ensure that data saturation is attained is to build a saturation grid listing the main topics, which makes it possible to observe information recurrence. Among other recommendations, there is the possibility of a second researcher conducting data codification and identifying idea repetition. And, finally, if new information is still obtained, other interviews must be conducted until saturation is attained ${ }^{(9)}$.

Inductive codification of interview data allows in-depth analysis. Moreover, literature recommends the employment of two researchers for primary codification, and a third codifier to ensure theoretical saturation and result reliability. Data codification and its later organization in emerging themes are utilized in the analysis and attainment of saturation ${ }^{(10)}$.

Therefore, theoretical saturation occurs when new elements cease to emerge from collected data. At this time, based on available empirical data and in the analytical and interpretative attributes from researchers, it is inferred that theoretical densification has been reached ${ }^{(3)}$.

Thus, the first themes that attained theoretical saturation were: use of clothes, at second interview; handling of the disease, at the eighth; play and physical activities, as well as feeding, at the ninth interview; finally, hydration, which reached theoretical saturation at the eleventh interview. Afterward, four additional interviews were conducted, which corresponds to a third of the sample, so the sampling conclusion by theoretical saturation could be reached safely.

When the interview script is adequate, the saturation point is generally reached in 15 interviews, at most. It is suggested that when saturation point be reached, $1 / 3$ of the number of interviews should be added. In other words, if saturation occurs in the ninth interview, three others should be performed ${ }^{(2)}$.

\section{Study limitations}

The limitation in this experience report is related to the fact that the primary sources were interviews with schoolchildren that possessed limited vocabulary, restricting data.

\section{Contributions for research}

The present study contributes to nursing research, since it is a reference for future qualitative studies in the field by having didactically described the steps taken until the attainment of theoretical saturation and sample closing, which makes scientific investigation more accurate. It also contributes to scientific literature, considering the scarcity of updated studies that can be employed as methodological reference.

\section{CONCLUSION}

In qualitative research, finding theoretical saturation is a determinant criterion to cease data collection and to define sample size.

This experience report made it possible to describe the five steps taken in sequence for the identification of theoretical data saturation in qualitative research performed with schoolchildren.

In conclusion, it is crucial to highlight, transparently, how a sample is defined in qualitative investigations. Even if there is strong resistance by qualitative researchers in using numbers as criteria for finding theoretical saturation, this step is necessary to observe methodological accuracy when producing scientific knowledge. The authors suggest that researchers should systematize the analysis of data obtained from qualitative research with samples closed by theoretical saturation.

\section{REFERENCES}

1. Fontanella BJB, Magdaleno Jr R. Saturação teórica em pesquisas qualitativas: contribuições psicanalíticas. Psicol Estudo [Internet]. 2012 [cited 2016 Oct 30];17(1):1763-71. Available from: http://www.redalyc.org/articulo.oa?id=287123554008 
2. Rhiry-Cherques RH. Saturação em pesquisa qualitativa: estimativa empírica de dimensionamento. Af-Rev PMKT[Internet]. 2009[cited 2016 Oct 15];4(08):20-7. Available from: http://www.revistapmkt.com.br/Portals/9/Edicoes/Revista_PMKT_003_02.pdf

3. Fontanella BJB, Luchesi BM, Saidel MGB, Ricas J, Turato ER, Melo DG. Amostragem em pesquisas qualitativas: proposta de procedimentos para constatar saturação teórica. Cad Saúde Pública [Internet]. 2011[cited 2016 Oct 30];27(2):389-94. Available from: http://www.scielo.br/pdf/csp/v27n2/20.pdf

4. Cho J, Trent A. Validity in qualitative research revisited. Qualit Res[Internet]. 2006 [cited 2016 Nov 01];6(3):319-40. Available from: http://journals.sagepub.com/doi/pdf/10.1177/1468794106065006

5. Ollaik LG, Ziller HM. Concepções de validade em pesquisas qualitativas. Educ Pesq[Internet]. 2012 [cited 2015 Dec 01];38(1):22941. Available from: http://www.scielo.br/pdf/ep/v38n1/ep448.pdf

6. Rocha-Pinto SR, Freitas AS, Maisonnave PR. Métodos interpretativistas em Administração: as implicações para o(a) pesquisador(a). Rev Adm FACES J[Internet]. 2010 [cited 2016 Oct 31];9(1):115-27. Available from: http://www.fumec.br/revistas/facesp/article/ view/176

7. Ullrich DR, Oliveira JS, Basso K, Visentini MS. Reflexões teóricas sobre confiabilidade e validade em pesquisas qualitativas: em direção à reflexividade analítica. Análise: Rev Adm PUCRS [Internet]. 2012[cited 2016 Nov 01];23(1):9-30. Available from: http:// revistaseletronicas.pucrs.br/ojs/index.php/face/article/viewFile/11329/9676

8. Fontanella BJB, Ricas J, Turato ER. Amostragem por saturação em pesquisas qualitativas em saúde: contribuições teóricas. Cad Saúde Pública [Internet]. 2008 [cited 2015 Dec 01];24(1):17-27. Available from: http://www.scielo.br/pdf/csp/v24n1/02

9. Fusch PI, Ness LR. Are We There Yet? Data Saturation in Qualitative Research. Qual Report [Internet]. 2015 [cited 2016 Dec 01];20(9):1408-16. Available from: http://www.nova.edu/ssss/QR/QR20/9/fusch1.pdf

10. Kreslake JM, Price KM, Sarfaty M. Developing effective communication materials on the health effects of climate change for vulnerable groups: a mixed methods study. BMC Public Health [Internet]. 2016 [cited 2016 Dec 01];16(1):946. Available from: https://bmcpublichealth.biomedcentral.com/articles/10.1186/s12889-016-3546-3 